\title{
Investigation of mixed infection of Goatpox and orf in Karnataka, India
}

\author{
Sumana Krishnappa ${ }^{1}$, Revanaiah Yogisharadhya ${ }^{1}$, Parimal Roy ${ }^{2}$, and Manjunatha Reddy \\ Gundallahalli Bayyappa ${ }^{1}$ \\ ${ }^{1}$ ICAR-National Institute of Veterinary Epidemiology and Disease Informatics \\ ${ }^{2}$ ICAR National Institute of Veterinary Epidemiology and Disease Informatics
}

July 9, 2020

\begin{abstract}
Sheep and goat pox (SGP) and orf are economically important transboundary animal diseases of small ruminants in India. The current study investigated an outbreak of mixed infection with Goatpox virus (GTPV) and Orf virus (ORFV) that occurred in an extensive system of goat rearing. Based on clinical sings and postmortem findings the disease was preliminary diagnosed as goat pox. The overall morbidity rate of $85.71 \%$ (60/70) was reported. The morbidity rate in young animals (100\%; 30/30) was higher than adults $(75 \% ; 30 / 40)$. The overall mortality rate recorded was $40 \%(28 / 70)$, whereas the case fatality rate of $20 \%$ and $66.67 \%$ in adults and young animals respectively. Preliminary molecular diagnosis revealed presence of capripoxvirus followed by specific confirmation as GTPV by PCR-RFLP and sequencing of major envelope protein gene P32 of CaPV. The ORFV was detected and confirmed by PCR amplification and sequencing of complete B2L gene from the scab samples collected from affected goats. Phylogenetic analysis and multiple sequence analysis of GTPV and ORFV virus isolates from current outbreak showed highest homology to their respective Indian isolates from different parts of country. The present study reported co-infection of GTPV and ORFV in goats, which might have contributed to high morbidity. Therefore, the outbreak is epidemiologically significant and emphasis should be given in future for continuous serological/clinical surveillance of mixed infections in small ruminants' health management.
\end{abstract}

\section{Hosted file}

Final manuscript.docx available at https://authorea.com/users/341355/articles/468288investigation-of-mixed-infection-of-goatpox-and-orf-in-karnataka-india

\section{Hosted file}

Figures . docx available at https://authorea.com/users/341355/articles/468288-investigation-ofmixed-infection-of-goatpox-and-orf-in-karnataka-india 